\title{
Effects of different physical forms of wheat grain in corn-based starter on performance of young Holstein dairy calves
}

\author{
N. Pezhveh, ${ }^{*}$ G. R. Ghorbani, ${ }^{*}$ P. Rezamand, $\dagger^{1}$ and M. Khorvash* \\ *Department of Animal Sciences, Isfahan University of Technology, Isfahan 84156 Iran \\ †Department of Animal and Veterinary Science, University of Idaho, Moscow 83844
}

\begin{abstract}
The objective of the present study was to examine the effects of partially replacing corn with 2 forms of wheat grain on daily intake of starter feed, average daily gain, feed efficiency, rumen $\mathrm{pH}$, fecal score, weaning weight, skeletal growth, and blood metabolites of dairy calves. Thirty-two male and female Holstein dairy calves ( $\mathrm{n}=8$ calves per treatment) were used in a completely randomized block design. At d 3 of age, individually housed calves were randomly allocated to different treatments consisting of a starter diet with $60 \%$ ground corn (control), a starter diet with $60 \%$ whole corn, a starter diet with $30 \%$ ground corn plus $30 \%$ ground wheat (GCGW), and a starter with $30 \%$ ground corn plus $30 \%$ whole wheat (GCWW), with all other components in a meal form. All calves had free access to water and feed throughout the study period and received $4 \mathrm{~L}$ of milk replacer/d from d 3 to 50 and $2 \mathrm{~L} / \mathrm{d}$ from d 50 to 52 ; weaning occurred at the end of d 52. Feed intake was recorded daily and body weight and skeletal growth measures were recorded on d 10 and every $10 \mathrm{~d}$ thereafter. Rumen $\mathrm{pH}$ was measured on d 30,45 , and 60 . Blood sample were collected on d 30 and every $10 \mathrm{~d}$ thereafter through d 70. Data were analyzed using MIXED procedures of SAS (SAS Institute Inc., Cary, NC). Over the experimental period (d 1-70), the starter intake for the GCWW group was significantly different from the control group, but not different from the other groups. Calves fed whole wheat had a significantly greater average daily gain compared with other groups over the experimental period (d 1-70). Feed efficiency was only better in calves fed the GCWW diet than the GCGW group for postweaning and overall periods. No differences were observed for preweaning in body length, hip height, or withers height among the treatments; however, differences were significant in heart girth and body barrel. Postweaning, some of the body measurements were greater in
\end{abstract}

Received November 13, 2013.

Accepted June 19, 2014.

${ }^{1}$ Corresponding author: rezamand@uidaho.edu calves fed the GCWW and GCGW starter diets. Blood glucose concentration reduced with age; however, blood urea nitrogen, $\beta$-hydroxybutyrate, albumin, and total protein increased with age. Treatment $\times$ time effects on blood urea nitrogen and total protein concentrations were detected. Blood urea nitrogen concentration (mg/ $\mathrm{dL}$ ) was affected by dietary treatments on d 30, 40, and 70 , but no significant difference was detected on d 50 and 60. Serum total protein concentration $(\mathrm{g} / \mathrm{dL})$ was also affected by dietary treatments on d 40 and 70 , but no significant difference was detected on d 40, 50, and 60 . Whereas rumen $\mathrm{pH}$ was significantly reduced for the control compared with the GCWW treatment on d 45, comparison of the fecal scores showed no detectable differences among the treatments. Overall, the results of the current study indicate that starter diets containing whole wheat and ground corn can improve performance in young dairy calves compared with diets containing ground corn/ground wheat, whole corn, or ground corn, under our experimental conditions.

Key words: dairy calf, wheat, performance

\section{INTRODUCTION}

Early transition from monogastric digestion to functional rumen microbial degradation in dairy calves is important for economic reasons (Khan et al., 2007). Rumen development in preweaned calves is affected by the intake of solid feed and its composition (Baldwin et al., 2004; Khan et al., 2007). Solid feeds, especially concentrate diets, stimulate rumen microbial proliferation and VFA production in calves, and subsequently initiate rumen development. Furthermore, growth and development of rumen papillae is aided by the fermentation of starter diets to VFA (Anderson et al., 1987) and allows the calf to change from a monogastric form of digestion to one characteristic of adult ruminants (Warner, 1991). When calves consume both calf starter and water at an early age, maturation of the rumen occurs at an earlier age compared with milk feeding alone (Warner, 1991). Cereal grains, such as corn, rice, wheat, barley, oats, and sorghum, are the primary sources of starch in the ruminant diet and are commonly used worldwide, espe- 
cially in calf starter (Huntington, 1997). These sources differ in their starch content, with wheat $(77 \%$ starch $)$ being the highest among the grains, followed by 70 to $73 \%$ starch in corn, sorghum, and rice (Huntington, 1997). Grain texture plays a major role in the rate and site of starch digestion in ruminants (Philippeau et al., 1999). Some grains (wheat, barley, and oats) are more rapidly fermented compared with corn and sorghum. Variations in starch granule structure may account for distinct rates of digestion patterns among cereal grains (Swan et al., 2006). Slower rates of digestion increase the amount of starch bypassing the rumen. Starch digested in the small intestine can produce more energy than fermentation because of more efficient use of digestive end products (glucose vs. VFA). Therefore, the site of starch digestion in the gastrointestinal tract affects performance and feed efficiency in cattle (Swan et al., 2006). Indeed, the physical form of starch, its relation to protein, and integrity of molecular structures containing starches can affect the availability of nutrients to microbes and their digestibility (Theurer et al., 1999).

We and others have investigated the effects of the physical form of calf starter (Abdelgadir and Morrill, 1995; Beharka et al., 1998) and grain processing (Lesmeister and Heinrichs, 2004; Jarrah et al., 2013) on feed intake, growth performance, and ruminal development of dairy calves; however, evaluation of the effects of various source of starches with differing processing rates in calf starter on feed consumption, nutrient intake, BW gain and skeletal growth, and metabolic responses is limited. The objective of the present study was to determine the effect of replacing corn with wheat (ground and whole) in starter diets on growth performance, rumen $\mathrm{pH}$, and blood metabolites of Holstein dairy calves during the first $70 \mathrm{~d}$ of age.

\section{MATERIALS AND METHODS}

\section{Animals and Experimental Design}

This experiment was conducted using 32 Holstein calves (16 males and 16 females), from birth to $70 \mathrm{~d}$ of age. Calves were separated from their dam within 2 $\mathrm{h}$ of birth, weighed, and moved into individual pens (1 $\times 2 \mathrm{~m}$; bedded with wood shavings that were replaced every 24 to $48 \mathrm{~h}$, as needed) where they were fed pooled colostrum at $10 \%$ of their BW at birth for the first 3 d. Physical contact among calves was minimized by pen arrangement. From d 4 to 50, calves were fed $4 \mathrm{~L}$ of milk replacer (20\% DM content; $2 \mathrm{~L}$ in the morning and $2 \mathrm{~L}$ in afternoon; $50 \%$ each time); then, $2 \mathrm{~L}$ of milk replacer (once per day) from d 50 to 52 ; and then all calves were weaned on d 53. Milk replacer (Zarinshad, Isfahan, Iran) contained $97.5 \%$ DM, and $31 \%$ fat, $25 \%$ protein, and $5.6 \%$ ash (on a DM basis). Calves had free access to water from a nipple waterer and were randomly assigned, after pairing for sex, into 4 dietary groups (8 calves per group: 4 males and 4 females). Holstein calves were fed 1 of 4 experimental diets: (1) starter containing $60 \%$ ground corn (control), (2) starter containing $60 \%$ whole corn (WC), (3) starter containing $30 \%$ ground corn plus $30 \%$ ground wheat (GCGW), or (4) starter containing 30\% ground corn plus $30 \%$ whole wheat (GCWW), with all the other components in a meal form $(\leq 2 \mathrm{~mm})$. The composition of the diets is presented in Table 1. Solid feed (starter) was offered ad libitum to all calves after d 3. Daily feed intake and weight gain were monitored over the experimental period. Body weight was determined at birth (43.7, 45.1, 44.1, and $44.4 \mathrm{~kg}$ for control, WC, GCGW, and GCWW, respectively) as well as on d 10 and then every $10 \mathrm{~d}$ thereafter. Calves were weaned between d 50 and 52. Measurements were continued after weaning through d 70 as detailed previously.

All procedures involving animals were conducted at the animal facilities of the Department of Animal Science at the Isfahan University of Technology (Isfahan, Iran) under protocols approved (2011-2012) by the Animal Care Advisory Committee of the Isfahan University of Technology.

\section{Sampling and Analysis}

Intake of starter was recorded daily throughout the experiment. Overall ADG, total DMI, and feed efficiency (feed efficiency $=\mathrm{kg}$ of BW gain $/ \mathrm{kg}$ of total DMI) were determined for the preweaning (d 1 to 52) and postweaning (d 52 to 70 ) periods. Body length (distance between the points of the shoulder and rump), heart girth (HG; circumference of the chest), withers height (distance from base of the front feet to the withers), hip height (distance from the base of the rear feet to the hip bone), body barrel (BB; circumference of the belly before feeding), and hip width (distance between the left and right trochanter major) measurements of calves were recorded at birth for preweaning (d 1 to 52), and for postweaning (d 52 to 70) stages on d 10 and every $10 \mathrm{~d}$ thereafter. Jugular blood samples were collected $3 \mathrm{~h}$ after morning feeding at various time points (on d 30, 40, 50, 60, and 70) throughout the experiment in evacuated tubes $(15 \mathrm{~mL})$ without anticoagulant. The samples were centrifuged at $1,000 \times g$ for 20 min at $4^{\circ} \mathrm{C}$ and serum was partitioned into aliquots and stored at $-20^{\circ} \mathrm{C}$ until analyzed for glucose, BUN, BHBA, albumin, and total protein by an automated 
Table 1. Ingredient composition (\% of DM) of calf starter diets and chemical compositions of starters (\% of $\mathrm{DM})$

\begin{tabular}{|c|c|c|c|c|}
\hline \multirow[b]{2}{*}{ Item } & \multicolumn{4}{|c|}{ Diet $^{1}$} \\
\hline & Control & WC & GCGW & GCWW \\
\hline \multicolumn{5}{|l|}{ Ingredient } \\
\hline Ground corn & 60 & & 30 & 30 \\
\hline Whole corn & & 60 & & \\
\hline Ground wheat & & & 30 & \\
\hline Whole wheat & & & & 30 \\
\hline Soybean meal & 31 & 31 & 29 & 29 \\
\hline Soybean (extruded) & 3 & 3 & 1 & 1 \\
\hline Wheat bran & 2 & 2 & 6 & 6 \\
\hline Salt & 0.5 & 0.5 & 0.5 & 0.5 \\
\hline $\mathrm{CaCO}_{3}$ & 1.4 & 1.4 & 1.4 & 1.4 \\
\hline Dicalcium phosphate & 0.5 & 0.5 & 0.5 & 0.5 \\
\hline Vitamins and minerals ${ }^{2}$ & 1.6 & 1.6 & 1.6 & 1.6 \\
\hline $\mathrm{DM}, \%$ & 91 & 91 & 93 & 93 \\
\hline \multicolumn{5}{|l|}{ Chemical composition } \\
\hline $\mathrm{CP}$ & 21.2 & 21.2 & 21 & 21 \\
\hline NDF & 13 & 13 & 12 & 12 \\
\hline NFC & 43.8 & 43.8 & 43.1 & 43.1 \\
\hline Ether extract & 4.1 & 4.1 & 3.8 & 3.8 \\
\hline $\mathrm{Ca}$ & 0.82 & 0.82 & 0.82 & 0.82 \\
\hline $\mathrm{P}$ & 0.55 & 0.55 & 0.58 & 0.58 \\
\hline Particle size, ${ }^{3} \mathrm{~mm}$ & 1.02 & 2.37 & 1.13 & 1.33 \\
\hline
\end{tabular}

analyzer (Technicon-RA 1000 Autoanalyzer; DRG Instruments GmbH, Marburg, Germany). Fecal scoring was performed on the same days as the blood sampling, as follows: $1=$ normal; $2=$ soft to loose; $3=$ loose to watery; $4=$ watery, mucous, and slightly bloody; and 5 $=$ watery, mucous, and bloody. At 30,45, and $60 \mathrm{~d}$ of age, ruminal contents were collected approximately 3 to $4 \mathrm{~h}$ postfeeding (morning) using a stomach tube and a large syringe, and the sample $\mathrm{pH}$ was immediately determined ( $\mathrm{pH}$ meter model M90; Corning Inc., Corning, NY).

\section{Chemical Analyses of Feed}

The starter diets were sampled for DM (oven drying at $60^{\circ} \mathrm{C}$ for $48 \mathrm{~h}$ ), NDF (Van Soest et al., 1991; using heat-stable $\alpha$-amylase and sodium sulfate), ether extract [AOAC, 1990; using a Tecator Soxtec System HT 1043 extraction unit (Tecator; Foss North America, Eden Prairie, MN)], NFC [NFC calculated as $100-(\%$ $\mathrm{NDF}+\% \mathrm{CP}+\%$ ether extract $+\%$ ash)], and $\mathrm{CP}$ [AOAC International, 2002; method 984.13; Kjeltec 1030 Auto Analyzer (Tecator, Höganäs, Sweden)] analyses (Table 1). Degradability parameters of DM and starch were measured (Table 2), as described by Correa et al. (2002).

\section{Statistical Analysis}

Analyses were performed using SAS (version 9.1; SAS Institute Inc., Cary, NC). Body weight, BW gain, skeletal growth, feed intake, nutrients intake, feed efficiency, rumen $\mathrm{pH}$, and blood metabolite (glucose, BUN, BHBA, albumin, and total protein) data were analyzed as a complete randomized block design using the RANDOM (calf nested within sex and treatment) and REPEATED measure (when measurements were performed over time; blood metabolites and rumen $\mathrm{pH}$ ) of PROC MIXED of SAS. The statistical model used for analyses was $\mathrm{Y}_{\mathrm{ijklm}}=\mu+\mathrm{t}_{\mathrm{i}}+\mathrm{d}_{\mathrm{ij}}+\mathrm{t}_{\mathrm{k}}+(\mathrm{t} \times \mathrm{t})_{\mathrm{ik}}+$ $\beta_{1}\left(B W_{1}\right)+s_{m}+e_{i j k l m}$, where $Y_{\mathrm{ijklm}}=$ observation or dependent variable, $\mu=$ the overall mean, $t_{i}=$ the effect of treatment $\mathrm{i}, \mathrm{d}_{\mathrm{ij}}=$ animal random effect with mean 0 and variance that is equal to the covariance between repeated measurements with animals, $t_{k}=$ the effect of period $\mathrm{k},(\mathrm{t} \times \mathrm{t})_{\mathrm{ik}}=$ the effect of interaction between treatment $\mathrm{i}$ and period $\mathrm{k}, \beta_{1}=$ regression coefficient of observations on birth weight $\left(\mathrm{BW}_{\mathrm{l}}\right)$ as a covariate considered only for growth traits (starter intake, ADG, feed efficiency, BW, and other body measurements), $\mathrm{s}_{\mathrm{m}}=$ the effect of sex $\mathrm{m}$, and $\mathrm{e}_{\mathrm{ijklm}}=$ random residual effect. Four different variance-covariance structures (unstructured, compound symmetry, autoregressive, 
Table 2. Degradability and effective degradability of DM and starch $( \pm \mathrm{SD})$ across dietary treatments

\begin{tabular}{|c|c|c|c|c|c|c|}
\hline Item $^{1}$ & \multicolumn{3}{|c|}{ Parameter $^{2}$} & $\mathrm{R}^{2}$ & $\mathrm{ED}^{3}$ & $\mathrm{SA}^{4}$ \\
\hline \multicolumn{7}{|l|}{ DM } \\
\hline WC & $0.30 \pm 0.01$ & $0.72 \pm 0.03$ & $0.04 \pm 0.004$ & 0.97 & 0.54 & \\
\hline GCGW & $0.36 \pm 0.01$ & $0.56 \pm 0.02$ & $0.06 \pm 0.004$ & 0.96 & 0.60 & \\
\hline GCWW & $0.33 \pm 0.02$ & $0.63 \pm 0.03$ & $0.06 \pm 0.006$ & 0.96 & 0.60 & \\
\hline GCGW & $0.21 \pm 0.01$ & $0.74 \pm 0.01$ & $0.18 \pm 0.009$ & 0.98 & & 0.72 \\
\hline GCWW & $0.18 \pm 0.02$ & $0.81 \pm 0.02$ & $0.22 \pm 0.02$ & 0.96 & & 0.77 \\
\hline
\end{tabular}

${ }^{1}$ Control $=60 \%$ ground corn; $\mathrm{WC}=60 \%$ whole corn; GCGW $=30 \%$ ground corn $+30 \%$ ground wheat; GCWW $=30 \%$ ground corn $+30 \%$ whole wheat.

${ }^{2} \mathrm{a}=$ quickly degradable fraction; $\mathrm{b}=$ insoluble but fermentable fraction; $\mathrm{c}=$ rate of DM or starch degradation.

${ }^{3}$ Effective degradability of DM, calculated at a passage rate of $0.08 / \mathrm{h}$.

${ }^{4}$ Starch availability, calculated at a passage rate of $0.08 / \mathrm{h}$.

and Toeplitz) for each variable were tested. Finally, the UN that resulted in the lowest Akaike and Bayesian information criteria was used (Littell et al., 1998). Data are presented as least squared means \pm standard error of the mean. Significance was declared at $P \leq 0.05$. When a significant treatment effect $(P \leq 0.05)$ was observed, separation of least squares means for significant effects was accomplished using the Tukey option within PROC MIXED of SAS.

\section{RESULTS}

No detectable effect was observed because of sex in any of the measurements tested; therefore, it was excluded from the statistical models. Degradability parameters of DM and starch were measured (Table 2). Effective degradability of DM (calculated at a passage rate of $0.08 / \mathrm{h}$ ) ranged from 0.54 (WC) to 0.60 (GCGW and GCWW). Furthermore, starch availability (calculated at a passage rate of $0.08 / \mathrm{h}$ ) ranged from 0.72 (GCGW) to 0.77 (GCWW). Intake of starter, ADG, and feed efficiency are presented in Table 3. Starter intake increased in calves with advancing age. The data show that starter intake in the preweaning period was not significantly different among calves; however, calves fed GCWW had a greater intake than the control and WC groups $(P=0.009)$ in the postweaning period. Over the experimental period (d 1-70), the starter intake for the GCWW group was significantly different from the control (Table 3), but not different from other groups $(0.79,0.8,0.87,1.02 \pm 0.06 \mathrm{~kg} / \mathrm{d}$ for control, WC, GCGW, and GCWW, respectively). Calves fed GCWW had a significantly greater ADG compared with other groups over the experimental period (d 1-70). The data from the preweaning period demonstrate that the GCWW group achieved a greater ADG compared with the WC group $(P=0.02)$. In the post-weaning period, the GCWW group achieved the greatest ADG compared with other groups, but not different from WC calves. In contrast, far lower ADG were recorded for calves fed the control or GCGW diets (1.06 kg vs. 0.74 and 0.62 , for GCWW, control, and GCGW, respectively). Calves fed GCWW had a better feed efficiency than the GCGW group, but were not different from the control or WC groups during the postweaning and the overall period (Table $3 ; P \leq 0.04$ for both). Body weight at birth and at the end of the weaning period (d 52) did not differ among treatments (Table 4), whereas BW on the last day of the experiment (d 70) was greater in GCWW compared with the control $(80.0,82.2,83.1$, and $90.1 \pm 0.2 \mathrm{~kg}$ for control, WC, GCGW, and GCWW, respectively). With regard to other measures of body growth, shown in Table 4 for the preweaning period and postweaning period, no differences were observed at preweaning in body length, hip height, or withers height among the treatments; however, differences were significant in $\mathrm{HG}$ and $\mathrm{BB}$ (Table 4). Preweaning, HG was greater in GCGW compared with control and WC groups but not compared with the GCWW group. Postweaning, HG was greater in calves fed the GCWW diet than the control diet; however, the WC and control groups both had a larger BB than the other 2 groups (Table 4).

Table 5 presents concentrations of serum glucose, albumin, and BHBA that were measured on d 30, 40, 50, 60 , and 70 in calves fed various starter diets. Whereas serum glucose concentrations decreased in all calves with advancing age, serum BUN, BHBA, albumin, and total protein concentrations increased $(P<0.01$ for 
Table 3. Total intake of starter, ADG, and feed efficiency in Holstein calves fed different grains from d 1 to 52 (preweaning), d 52 to 70 (postweaning), and d 1 to 70 (overall) $)^{1}$

\begin{tabular}{|c|c|c|c|c|c|}
\hline \multirow[b]{2}{*}{ Parameter } & \multicolumn{4}{|c|}{ Diet $^{1}$} & \multirow[b]{2}{*}{ SEM } \\
\hline & Control & WC & GCGW & GCWW & \\
\hline d 52 to 70 (postweaning) & $1.78^{\mathrm{b}}$ & $1.89^{\mathrm{b}}$ & $1.93^{\mathrm{ab}}$ & $2.32^{\mathrm{a}}$ & 0.11 \\
\hline d 1 to 70 (overall) & $0.79^{\mathrm{b}}$ & $0.8^{\mathrm{ab}}$ & $0.87^{\mathrm{ab}}$ & $1.02^{\mathrm{a}}$ & 0.06 \\
\hline \multicolumn{6}{|l|}{$\mathrm{ADG}, \mathrm{kg} / \mathrm{d}$} \\
\hline d 1 to 70 (overall) & $0.57^{\mathrm{b}}$ & $0.52^{\mathrm{b}}$ & $0.54^{\mathrm{b}}$ & $0.65^{\mathrm{a}}$ & 0.02 \\
\hline \multicolumn{6}{|l|}{ Feed efficiency } \\
\hline d 1 to 52 (preweaning) & 0.43 & 0.45 & 0.46 & 0.46 & 0.01 \\
\hline d 52 to 70 (postweaning) & $0.39^{\mathrm{ab}}$ & $0.44^{\mathrm{ab}}$ & $0.35^{\mathrm{a}}$ & $0.47^{\mathrm{b}}$ & 0.02 \\
\hline d 1 to 70 (overall) & $0.43^{\mathrm{ab}}$ & $0.44^{\mathrm{ab}}$ & $0.43^{\mathrm{a}}$ & $0.47^{\mathrm{b}}$ & 0.01 \\
\hline
\end{tabular}

\footnotetext{
${ }^{\mathrm{a}, \mathrm{b}}$ Least squares means within a row with different superscript letters differ at $P<0.05$ for treatment effect.

${ }^{1}$ Control $=60 \%$ ground corn; $\mathrm{WC}=60 \%$ whole corn; GCGW $=30 \%$ ground corn $+30 \%$ ground wheat; GCWW $=30 \%$ ground corn $+30 \%$
} whole wheat.

all). Dietary treatments affected blood concentrations of some of the metabolites tested. Interestingly, significant treatment $\times$ time interactions were observed for BUN and total protein concentrations (Figure 1; $P<$ 0.001 and $P=0.01$, respectively). Blood urea nitrogen $(\mathrm{mg} / \mathrm{dL})$ was affected by dietary treatments on d 30 , 40 , and 70, but no significant difference was detected on $\mathrm{d} 50$ and 60 . Serum total protein $(\mathrm{g} / \mathrm{dL})$ was also affected by dietary treatments on d 40 and 70 , but no significant difference was detected on d 40, 50, and 60 . Table 6 shows ruminal $\mathrm{pH}$ measurement. Ruminal $\mathrm{pH}$ at 30 and $60 \mathrm{~d}$ of age did not differ across treatments, but at $45 \mathrm{~d}$ of age, calves fed the GCWW diet differed from calves fed the control and GCGW diets $(P$ $<0.05)$. No significant treatment effect was detected for rumen $\mathrm{pH}$ at other time point tested. Comparison of the fecal scores showed no detectable differences among the dietary treatments (data not shown).

Table 4. Body weight and other growth measurements for Holstein calves fed different forms of cereal grains

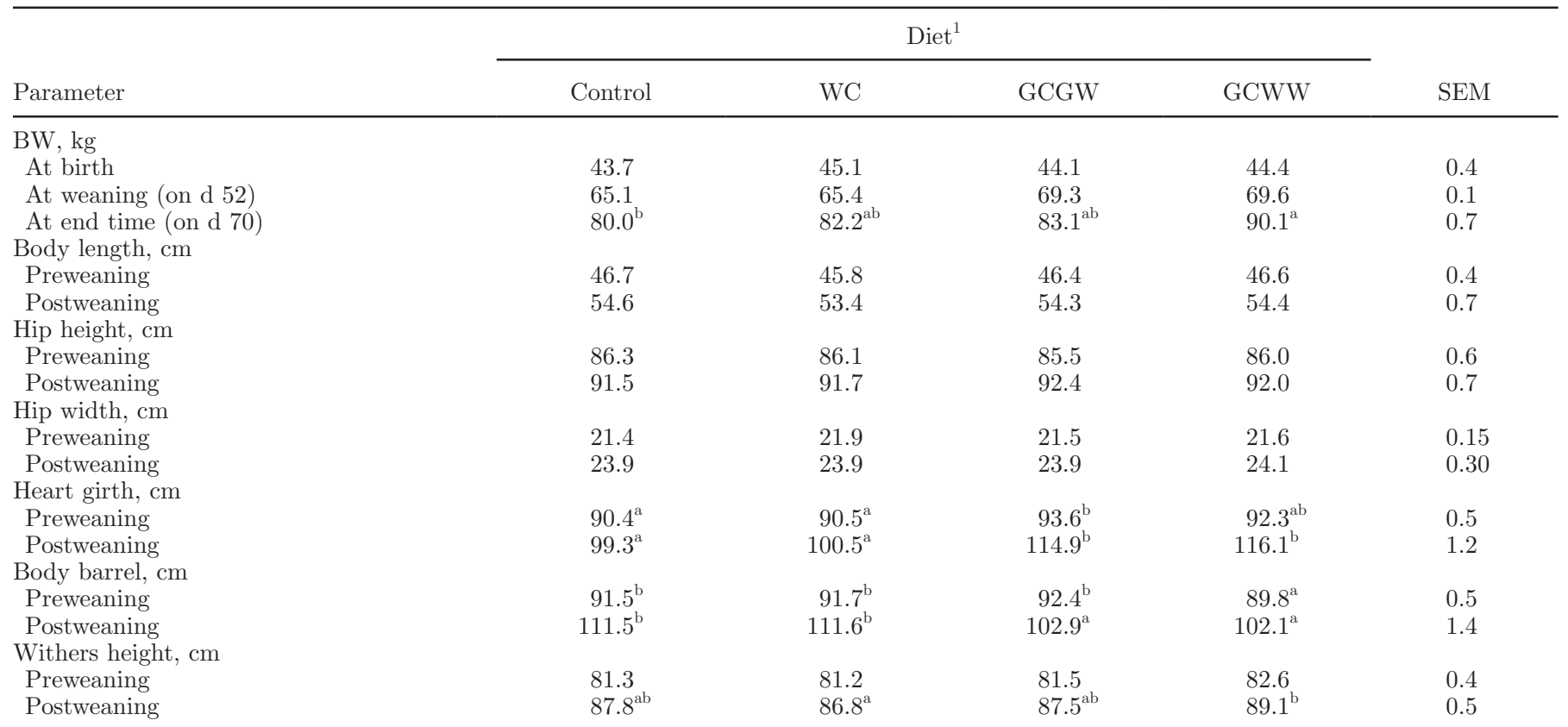

\footnotetext{
${ }^{\mathrm{a}, \mathrm{b}}$ Least squares means within a row with different superscript letters differ at $P \leq 0.05$ for treatment effect.

${ }^{1}$ Control $=60 \%$ ground corn; WC $=60 \%$ whole corn; GCGW $=30 \%$ ground corn $+30 \%$ ground wheat; GCWW $=30 \%$ ground corn $+30 \%$ whole wheat.
} 
Table 5. Blood glucose, BHBA, and albumin concentrations for Holstein calves fed different forms of cereal grains

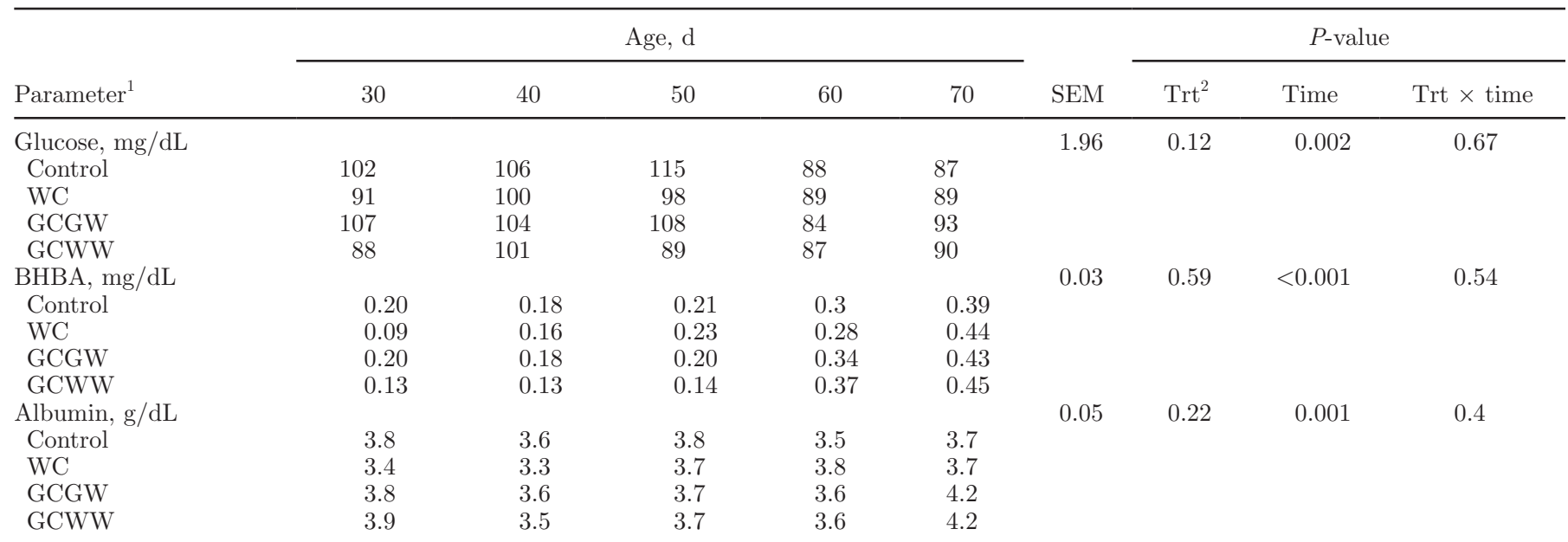

${ }^{1}$ Control $=60 \%$ ground corn; WC $=60 \%$ whole corn; GCGW $=30 \%$ ground corn $+30 \%$ ground wheat; GCWW $=30 \%$ ground corn $+30 \%$ whole wheat.

${ }^{2}$ Trt $=$ treatment.

\section{DISCUSSION}

The results of the present study demonstrate that the physical form of dietary grains affects the performance of calves. Wheat starch ferments more rapidly than corn (Philippeau et al., 1999). Differences in starch granule size, shape, and interactions between amylose and surface compounds can alter the rate of enzymatic digestion of corn and wheat starches (Nocek and Tamminga, 1991; Kotarski et al., 1992). These variations may affect the solid feed intake, quantity, and proportion of VFA in the rumen and, thus, the development and performance of calves during preweaning and early postweaning periods.

Porter et al. (2007) reported greater ADG, starter intake, and earlier initiation of rumination in neonatal calves fed a coarse meal diet versus a finely ground meal. In the present study, greater starch intake, possibly greater availability, and oxidation of glucose might have contributed, in part, to improved energy efficiency. This may have been achieved by sparing other oxidizable substrates, such as amino acids (Huntington et al., 2006) and thus greater BW gain in calves fed the GCWW diet compared with those fed the control (ground corn), WC, and GCGW diets (Table 3). Greater starch degradation and starch availability (calculated at a passage rate of $0.08 / \mathrm{h}$ ) of GCWW compared with other treatments (Table 2) lend support to this notion. No measurement of amino acids status, however, was performed in the present study. Previous work (Gardner, 1967; Kertz et al., 1979) noted that calves consumed less of starters with fine particles compared with starters containing large particles. In the present study, starter intake was improved during preweaning (d 52-70) and the overall period (d 1-70) when whole wheat was fed (Table 3), but this did not correlate well with particle size (Table 1). Greenwood et al. (1997) suggested that fine feed particles have a more drastic effect on keratinization of ruminal epithelia and, subsequently, on decreasing the metabolic activity of ruminal tissues. Furthermore, Węglarzy and Bilik (2008) reported that when compared with conventional feeding concentrates, having whole corn and oat grains in the diet had a more significant effect on the feed conversion and growth rate of heifer calves, 6 to $90 \mathrm{~d}$ of age. Coverdale et al. (2004) restricted starter intake and reported an increased ADG when calves were fed a textured starter compared with a finely ground starter.

Greater starch consumption may trigger hepatic glucogenic activity in growing and lactating cattle (Huntington et al., 2006) because of a greater availability of glucogenic precursors (particularly propionate). In the present study, calves fed GCWW had a greater starter intake (d 1 to 70; Table 3), greater starch degradation rate, and starch availability (calculated at passage rate of $0.08 / \mathrm{h}$; Table 2) than control calves. Greater hepatic glucogenic activity and, consequently, greater glucose supply in cattle result in greater irreversible loss of glucose, with a significant portion lost as $\mathrm{CO}_{2}$. In the present study, however, plasma BHBA was measured on peripheral blood samples (Table 5) and thus values reported also include any BHBA converted from butyrate and acetate in the liver. In addition, changes between rumen butyrate and plasma BHBA and their relationship to rumen epithelial metabolic activity have not been fully established. 

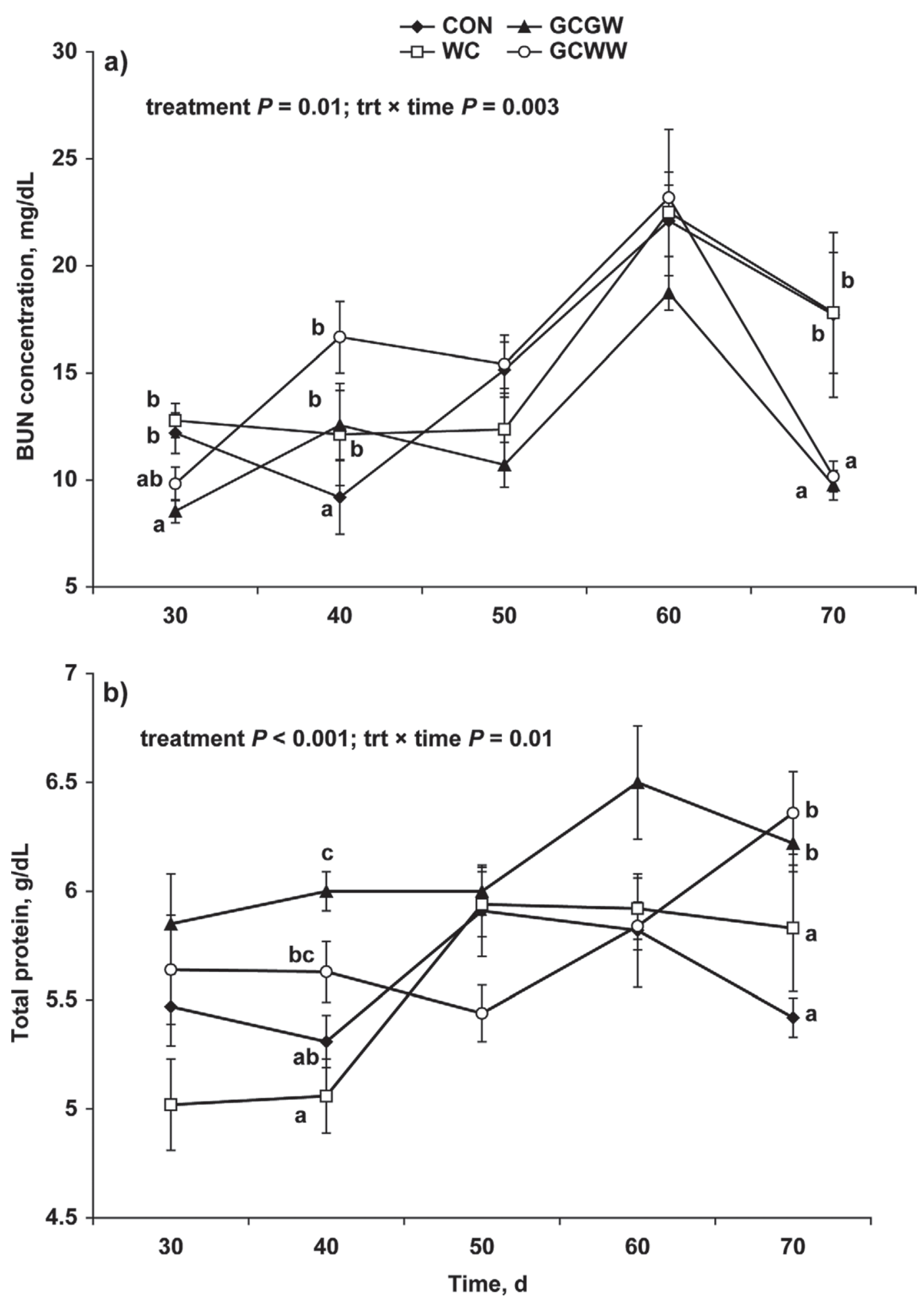

Figure 1. Serum concentrations (error bars indicate SEM) of urea nitrogen (a) and total protein (b) for Holstein calves fed different calf starters, including $60 \%$ ground corn (control; black diamond), $60 \%$ whole corn (WC; white square), $30 \%$ ground corn $+30 \%$ ground wheat (GCGW; black triangle), and 30\% ground corn $+30 \%$ whole wheat (GCWW; white circle) over the study period. Concentrations of both urea nitrogen (a) and total protein (b) were affected by interaction between treatment and time $(P \leq 0.01$ for both). Different letters (a and b) at each time point indicate a significant effect at $P<0.05$ 
Table 6. Rumen $\mathrm{pH}$ for Holstein calves fed different forms of cereal grains

\begin{tabular}{lccccccc}
\hline & \multicolumn{3}{c}{ Age, $\mathrm{d}$} & & \multicolumn{3}{c}{$P$-value } \\
\cline { 2 - 3 } \cline { 6 - 8 } Parameter $^{1}$ & 30 & 45 & 60 & & $\operatorname{Trt}^{2}$ & Time & Trt $\times$ time \\
\hline Mean pH & & & & & 0.04 & $<0.001$ & 0.53 \\
Control & 5.02 & $5.52^{\mathrm{b}}$ & 5.56 & & & & \\
WC & 5.14 & $5.76^{\mathrm{ab}}$ & 6.01 & & & & \\
GCGW & 5.11 & $5.40^{\mathrm{b}}$ & 5.99 & & & & \\
GCWW & 5.20 & $6.10^{\mathrm{a}}$ & 6.08 & & & & \\
\hline
\end{tabular}

$\overline{\mathrm{a}, \mathrm{b}}$ Least squares means within a column with different superscript letters differ at $P \leq 0.05$ for treatment effect. ${ }^{1}$ Control $=60 \%$ ground corn; $\mathrm{WC}=60 \%$ whole corn; GCGW $=30 \%$ ground corn $+30 \%$ ground wheat; $\mathrm{GCWW}=30 \%$ ground corn $+30 \%$ whole wheat.

${ }^{2}$ Trt $=$ treatment.

It has been shown that a greater proportion of largersize particles in the ration (including whole grains) not only affects the rumen development, but causes mechanical abrasion of the epithelium, thus preventing keratinization (Beharka et al., 1998). Additionally, mechanical stimulation may increase the blood supply to the epithelium, thus enhancing the metabolic activity and development of the rumen. However, in the present study, no marker of keratinization or development of rumen papillae was performed. The lower ruminal $\mathrm{pH}$ for calves that consumed ground starter diets compared with that of calves fed whole grains in the present study (Table 6) may be related to the intake of solid feed and starch fermentation pattern. Ground-wheat starch ferments more rapidly than whole-wheat starch (Philippeau et al., 1999). Differences in starch granule size, shape, and interactions between amylose and surface compounds can also alter the rate of enzymatic digestion of corn and wheat starches (Nocek and Tamminga, 1991; Kotarski et al., 1992).

Blood urea nitrogen concentration has a positive linear relationship with dietary $\mathrm{CP}$ intake, its ruminal degradability, and resultant ruminal ammonia concentration in cattle (Broderick and Clayton, 1997; Lohakare et al., 2012). In the present study, glucose concentration did not differ among treatments, but was numerically greater for GCGW. Khan et al. (2007) reported a rapid surge in solid feed consumption and reduced blood glucose levels in Holstein calves with reduced milk supply.

\section{CONCLUSIONS}

Results from the present study indicate that over the experimental period (d 1-70), the starter intake for GCWW was greater than for the control diet, but not different from other groups. Furthermore, over the experimental period (d 1-70), calves fed GCWW had a greater ADG compared with other groups. During the preweaning period, the GCWW group achieved a greater $\mathrm{ADG}$ compared with the WC group. In the postweaning period, the GCWW group achieved the best ADG; the GCWW group was not different from the WC group but did differ from other groups. Body weight on the last day of experiment (on d 70) was greater in GCWW compared with control calves; however, no difference was detected in BW at birth or at the end of weaning period (d 52). Calves fed GCWW had a better feed efficiency than the GCGW group but were not different from control or WC calves during the postweaning and the overall period. Overall, growth and production measures collectively showed improved performance by the GCWW group relative to other groups in the present study. Blood glucose concentration decreased with age; however, blood BUN, BHBA, albumin, and total protein concentrations increased with advancing age. Dietary treatments affected BUN and total protein concentrations; diets containing wheat seemed to have greater concentrations at various time points. Rumen $\mathrm{pH}$ was slightly greater for GCWW compared with other groups. Overall, results of the current study demonstrated that under our experimental conditions, starter diets containing a mix of whole wheat and ground corn improved performance in young dairy calves compared with diets containing whole or ground corn as well as corn mixed with ground wheat. Further research is needed to assess direct rumen development measures.

\section{REFERENCES}

Abdelgadir, I. E. O., and J. L. Morrill. 1995. Effect of processing sorghum grain on dairy calf performance. J. Dairy Sci. 78:2040-2046.

Anderson, K. L., T. G. Nagaraja, and J. L. Morrill. 1987. Ruminal metabolic development in calves weaned conventionally or early. J. Dairy Sci. 70:1000-1005.

AOAC (Association of Official Analytical Chemists). 1990. Official Methods of Analysis. 15th ed. AOAC, Arlington, VA.

AOAC International. 2002. Official Methods of Analysis. 17th ed. Rev. 1. AOAC International, Arlington, VA.

Baldwin, R. L., K. R. McLeod, J. L. Klotz, and R. N. Heitmann. 2004. Rumen development, intestinal growth and hepatic metabolism in the pre- and postweaning ruminant. J. Dairy Sci. 87(ESuppl.):E55-E65. 
Beharka, A. A., T. G. Nagaraja, J. L. Morrill, G. A. Kennedy, and R. D. Klemm. 1998. Effects of form of the diet on anatomical, microbial, and fermentative development of the rumen of neonatal calves. J. Dairy Sci. 81:1946-1955.

Broderick, G. A., and M. K. Clayton. 1997. A statistical evaluation of animal and nutritional factors influencing concentrations of milk urea nitrogen. J. Dairy Sci. 80:2964-2971.

Correa, C. E. S., R. D. Shaver, M. N. Pereira, L. G. Laur, and K. Kohn. 2002. Relationship between corn vitreousness and ruminal in situ starch degradability. J. Dairy Sci. 85:3008-3012.

Coverdale, J. A., H. D. Tyler, J. D. Quigley III, and J. A. Brumm. 2004. Effect of various levels of forage and form of diet on rumen development and growth in calves. J. Dairy Sci. 87:2554-2562.

Gardner, R. W. 1967. Acceptability and nutritional response comparisons between calf starters. J. Dairy Sci. 50:729-734.

Greenwood, R. H., J. L. Morrill, E. C. Titgemeyer, and G. A. Kennedy 1997. A new method of measuring diet abrasion and its effect on the development of the fore-stomach. J. Dairy Sci. 80:2534-2541.

Huntington, G. B. 1997. Starch utilization by ruminants: From basics to the bunk. J. Anim. Sci. 75:852-867.

Huntington, G. B., D. L. Harmon, and C. J. Richards. 2006. Sites, rates, and limits of starch digestion and glucose metabolism in growing cattle. J Anim. Sci. 84(E. Suppl.):E14-E24.

Jarrah, A., G. R. Ghorbani, P. Rezamand, and M. Khorvash. 2013. Effects of processing methods of barley grain in starter diets on feed intake and performance of dairy calves. J. Dairy Sci. 96:72697273 .

Kertz, A. F., L. R. Prewitt, and J. P. Everett Jr. 1979. An early weaning calf program: Summarization and review. J. Dairy Sci. 62:1835-1843

Khan, M. A., H. J. Lee, W. S. Lee, H. S. Kim, S. B. Kim, K. S. Ki, S. J. Park, J. K. Ha, and Y. J. Choi. 2007. Starch source evaluation in calf starter: I. Feed consumption, body weight gain, structural growth, and blood metabolites in Holstein calves. J. Dairy Sci. 90:5259-5268

Kotarski, S. F., R. D. Waniska, and K. K. Thurn. 1992. Starch hydrolysis by the rumen microflora. J. Nutr. 122:178-190.
Lesmeister, K. E., and A. J. Heinrichs. 2004. Effects of corn processing on growth characteristics, rumen development, and rumen parameters in neonatal dairy calves. J. Dairy Sci. 87:3439-3450.

Littell, R. C., P. R. Henry, and C. B. Ammerman. 1998. Statistical analysis of repeated measures data using SAS procedures. J. Anim. Sci. 76:1216-1231.

Lohakare, J. D., H. van de Sand, K. Gerlach, A. Hosseini, M. Mielenz, H. Sauerwein, M. Pries, and K. H. Südekum. 2012. Effects of limited concentrate feeding on growth and blood and serum variables, and on nutrient digestibility and gene expression of hepatic gluconeogenic enzymes in dairy calves. J. Anim. Physiol. Anim. Nutr. (Berl.) 96:25-36.

Nocek, J. E., and S. Tamminga. 1991. Site of digestion of starch in the gastrointestinal tract of dairy cows and its effect on milk yield and composition. J. Dairy Sci. 74:3598-3629.

Philippeau, C., C. Martin, and B. Michalet-Doreau. 1999. Influence of grain source on ruminal characteristics and rate, site, and extent of digestion in beef steers. J. Anim. Sci. 77:1587-1596.

Porter, J. C., R. G. Warner, and A. F. Kertz. 2007. Effect of fiber level and physical form of starter on growth and development of dairy calves fed no forage. Prof. Anim. Sci. 23:395-400.

Swan, C. G., J. G. P. Bowman, J. M. Martin, and M. J. Giroux. 2006. Increased puroindoline levels slow ruminal digestion of wheat (Triticum aestivum L.) starch by cattle. J. Anim. Sci. 84:641-650

Theurer, C. B., J. T. Huber, A. Delgado-Elorduy, and R. Wanderley. 1999. Invited review: Summary of steam-flaking corn or sorghum grain for lactating dairy cows. J. Dairy Sci. 82:1950-1959.

Van Soest, P. J., J. B. Robertson, and B. A. Levis. 1991. Methods for dietary fiber, neutral detergent fiber, and nonstarch polysaccharides in relation to animal nutrition. J. Dairy Sci. 74:3583-3597.

Warner, R. G. 1991. Nutritional factors affecting the development of a functional ruminant a historical perspective. Pages 1-12 in Proc. Cornell Nutr. Conf. Cornell University, Ithaca, NY.

Weglarzy, K., and K. Bilik. 2008. Effect of diverse feeding regimes on rearing performance of Holstein-Friesian red heifer calves. Ann. Anim. Sci. 2:145-154. 